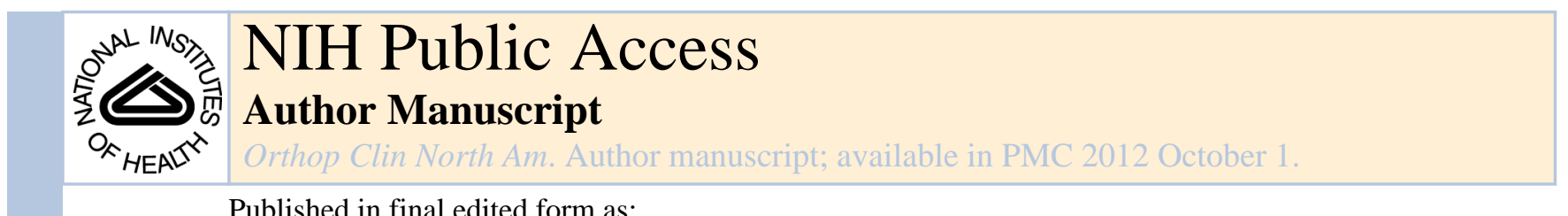

Orthop Clin North Am. 2011 October ; 42(4): 487-499. doi:10.1016/j.ocl.2011.07.001.

\title{
Biomechanics of Intervertebral Disc Degeneration
}

\author{
Nozomu Inoue, M.D., Ph.D. ${ }^{a}\left[\right.$ Professor] and Alejandro A. Espinoza Orías, Ph.D. ${ }^{\text {[ }}$ [Assistant \\ Director] \\ aDepartment of Orthopedic Surgery and Director of Spine Biomechanics Laboratory, Rush \\ University Medical Center, Chicago, IL \\ bSpine Biomechanics Laboratory, Rush University Medical Center, Chicago, IL
}

\section{Keywords}

biomechanics; intervertebral disc; degeneration

\section{Introduction}

The intervertebral disc has a composite structure consisting of a gelatinous proteoglycanrich nucleus pulposus surrounded by a collagen-rich anulus fibrosus. The proteoglycan in the nucleus pulposus provides high water content within the nucleus pulposus, and in turn, contributes to sustain large loads applied to the vertebral body. The load is distributed evenly to the anulus fibrosus through hydrostatic pressure. The fiber orientation of the anulus fibrosus is suitable to resist hoop stresses generated by the hydrostatic pressure in the healthy conditions (see article by Grunhagen et $a l$ ).

Degenerative changes in the biomechanical properties can occur in the nucleus pulposus and anulus fibrosus tissues individually. These can be shown as changes in material properties of each tissue. Degenerative changes in structural properties may be represented as consequences of these changes in material properties of the substructure of the disc. However, degenerative structural changes in the disc, such as loss of the volume of the nucleus pulposus and fissures in anulus fibrosus, can only be evaluated by analysis of structural parameters. It is important to understand how these changes affect the function of the motion segment and relate to symptoms such as low back pain (LBP) (see article by Karppinen et al).

In this review, we will address on the degenerative changes in the material properties of nucleus pulposus and anulus fibrosus followed by the changes in structural properties of the entire disc, with an emphasis on the degenerative changes in viscoelastic properties of the whole disc. Instability of the motion segment as a consequence of the structural failure associated with the degenerative changes on the disc will be followed. Finally, instability of

(C) 2011 Elsevier Inc. All rights reserved.

Corresponding author: Nozomu Inoue, M.D., Ph.D., Department of Orthopedic Surgery, Rush University Medical Center, 1611 West Harrison Street, Orthopedic Building, Room 205 J, Chicago, IL 60612, Nozomu_Inoue @ rush.edu, Phone: 312-942-8151, Fax: 312-942-2101. ${ }^{b}$ Coauthor: Alejandro A. Espinoza Orías, Ph.D., Department of Orthopedic Surgery, Rush University Medical Center, 1611 West Harrison Street, Orthopedic Building, Room 205 L, Chicago, IL 60612, Alejandro_Espinoza@rush.edu, Phone: 312-942-2589, Fax: 312-942-2101.

Publisher's Disclaimer: This is a PDF file of an unedited manuscript that has been accepted for publication. As a service to our customers we are providing this early version of the manuscript. The manuscript will undergo copyediting, typesetting, and review of the resulting proof before it is published in its final citable form. Please note that during the production process errors may be discovered which could affect the content, and all legal disclaimers that apply to the journal pertain. 
the lumbar spine, which has been considered as one of the significant causes for mechanical LBP will be reviewed.

\section{Material Properties of the Degenerative Intervertebral Disc Components}

\section{Nucleus Pulposus}

The disc degeneration process affects several of the structures differently and apparently at different times during its progression. It is important to bear in mind the impaired synthesis of the disc matrix when describing this sequence of events, as it involves all of its components at different time points. ${ }^{1-4}$ The process is thought to start in the nucleus pulposus, exhibiting a decrease in its proteoglycan concentration ${ }^{3,5-9}$ and gradual change in collagen type that transitions into a more fibrotic tissue. ${ }^{10}$ These factors effectively dehydrate the nucleus pulposus down from a peak nucleus water content in the adult disc, of approximately 70 to $80 \% .{ }^{11}$ Recently, Murakami et al ${ }^{12}$ quantified the difference in water content between old ( 3 years) and young ( 6 months) anulus fibrosus and nucleus pulposus tissue of rabbits, showing significant differences among them. Additionally, the nucleus pulposus GAG, DNA, aggrecan and collagen types I and II contents were significantly larger in the younger tissue. Evidence like this shows that the nucleus tissue is the most affected. Its decay constitutes perhaps one of the largest enablers of furthering disc degeneration. This transition into a more fibrotic type of tissue produces a stiffer nucleus pulposus and the 'shock-absorbing' properties of the disc are severely limited.

The nucleus pulposus, usually referred to as fluid, ${ }^{13-17}$ loses its hydrostatic pressure feature. ${ }^{1,18-23}$ A more fibrotic (increased collagen in nucleus pulposus) ${ }^{10,24}$ tissue will not behave in the same manner as a fluid/gel nucleus pulposus. The nucleus pulposus tissue undergoes a process of stiffening by means of gradual loss of proteoglycans and change of collagens from Type II to Type I, ${ }^{3,24}$ becoming a more fibrous and solid tissue, ${ }^{25,26}$ which was found to amalgamate into one solid phase with the anulus fibrosus in $75 \%$ of the cases from the 6th to 8th decade in a cadaveric study by Haefeli et al. ${ }^{10}$ The loss of proteoglycans originates the decrease of swelling pressure in the nucleus pulposus ${ }^{27}$, identified as the main load-bearing mechanism in the non-degenerate nucleus pulposus. ${ }^{28}$ As a consequence, load mechanics are altered and for a period, during the initial phase of degeneration, the disc is unstable.

\section{Anulus Fibrosus}

The mechanical behavior of the anulus fibrosus has been well documented in terms of tensile and compressive tests, but not so much in shear. Tensile behavior corresponds to the circumferential direction on the annular wall and was characterized in static and dynamic tests in order to explain its mechanism to resist hoop stresses produced by the nucleus pulposus hydrostatic pressure ${ }^{29}$. These two loading conditions are commonly accepted to simulate the body weight borne by the spinal column (compression) and the additional stresses seen in outward lateral bending and flexion/extension (tension). The largest strengths are usually seen when loading the lamellae in the direction of the reinforcing fibers. The arrangement of the elastic fibers plays a very important role in the overall mechanical properties of the anulus fibrosus. ${ }^{30,31}$ Elastic anisotropy in the anulus ${ }^{32}$ is maintained with degeneration, with posterolateral and outer lamellae regions having decreases of about $30-50 \%$ with advancing degeneration. ${ }^{33-36}$

However, in cases like spondylolisthesis, anterior-posterior shear seems to be the dominant failure mode and this has not been studied, as well as shear within the anulus lamellae in cases of annular failure leading to herniation. In the degenerate anulus fibrosus, the fiber patterns become disorganized, and the elastic response also varies consequently. ${ }^{37,38}$ The 
elastic properties in an intact model are anisotropic and highly nonlinear ${ }^{39,40}$. This nonlinearity, exhibited by a 'toe-region' on the stress-strain curves is common to cartilaginous tissues ${ }^{41-46}$. Moreover, the response of degenerate anulus fibrosus tissue has been shown to be of a two-fold increase in the toe-region modulus in tensile testing, which was correlated with age, as well as fiber realignment towards the loading direction. ${ }^{47,48}$ Dynamic viscoelastic testing has shown that the dynamic modulus of anulus fibrosus increases with degeneration at tensile strains greater than $6 \% .{ }^{49}$ Earlier quasi-static test results from Acaroglu et al ${ }^{33,35}$ described a strong influence of degeneration on elastic properties such as the Poisson's ratio, failure stress, and strain energy density of the anulus fibrosus. The work by Guerin et al ${ }^{47}$ reports no other significant changes in the elastic properties of the anulus fibrosus tissue.

In addition to elastic anisotropy, permeability also has been shown to vary spatially and is influenced by age, degeneration and water content in the disc. ${ }^{50}$ These values have been incorporated to a finite element model simulation by Natarajan et al $^{51}$ and they showed their effect on disc height and annular failure.

\section{Degenerative Changes in Structural Properties of the Motion Segment}

The function of the motion segment is to provide the spine with axial stability while allowing mobility. ${ }^{52}$ The intervertebral disc is responsible for carrying enormous amounts of compressive loading while maintaining flexibility. ${ }^{53}$ The load on the disc is mainly compressive, but it is also subjected to other types of loads such as tensile and shear stresses. ${ }^{26,54}$ As the compressive load is subjected to the disc, hydrostatic pressure develops within the inner core of gelatinous nucleus pulposus, which pushes outward causing the outer ring of fibrous anulus fibrosus to bulge and experience tensile stress in the fibers. ${ }^{55}$ Loads on the lumbar disc (L3/4) of volunteers performing different body postures ${ }^{19,56,57}$ as well as disc pressures ${ }^{58}$ have been measured in vivo. These studies revealed that the load on the L3/4 level disc in a sitting position and in a standing position with 20 degrees of flexion was $250 \%$ of the total body weight, although the portion of the body above the L3/4 level represented only $60 \%$. Such large loads have been validated with mathematical models. ${ }^{59,60}$ This suggests that the load on the lumbar disc is composed of external and internal inputs. ${ }^{54}$ The external load is the weight of the body above the lumbar disc, and the internal load is the muscle force required to stabilize the spine under different postures. Increases in disc pressure should also be expected when a fluid is injected, as Andersson and Schultz ${ }^{61}$ have shown, when they inquired about the effects of injecting saline in a disc, and found varied responses in cases where the injected fluid was retained, notably the large increases in pressure (up to $83 \%$ ). On the other hand, a decrease in pressure was observed in the degenerated disc. ${ }^{16}$

A number of animal models have been established to investigate degenerative changes in structural properties of the lumbar motion segment. A commonly used mechanical damage method to cause disc degeneration is the needle puncture or stab wound. Several researchers have recently arrived at the same conclusions when reporting that the diameter of the wound has to be large enough to create degeneration. ${ }^{62-64}$ Korecki et al ${ }^{65,66}$ have shown that in an in vitro cyclic testing setting, bovine discs showed immediate and progressive differences in the dynamic modulus and stiffness of the anulus fibrosus tissue after puncture. Aside from the lamellar disturbances, cell viability and matrix remodeling were observed. Another animal model (ovine) of disc degeneration from induced lesions has also shown regeneration in the mid anulus fibrosus wall. ${ }^{67}$ In a different loading condition, a murine tail model has shown also differences in the anulus fibrosus tissue as a consequence of dynamic compression, but did not achieve degenerate disc quality after long cycles of compression. ${ }^{68}$ In all, these reports suggest that puncture injuries lead to degenerative remodeling including 
granulation tissue, which current image-based diagnostics methods might not be able to distinguish. ${ }^{69}$

MacLean et al ${ }^{70}$ investigated static viscoelastic behaviors of rat caudal motion segments, vertebrae and isolated disc explants under different permeability conditions and demonstrated that differences in endplate permeability conditions had a significant effect on the viscoelastic behaviors. Johannessen et al ${ }^{71}$ demonstrated a decrease in stress-relaxation after ten thousand cycles of compressive loading in adult sheep lumbar motion segments and recovery of the stress-relaxation after 18 hours of unloading in PBS solution, suggesting intervertebral disc fluid transport during loading and unloading.

Boxberger et al ${ }^{72,73}$ used a degenerative disc model in rat by injection of Chondroitinase$\mathrm{ABC}$ to the discs. In this model, nucleus pulposus degeneration has been successfully induced through with GAG loss as a consequence of Chondroitinase-ABC injection to the discs, which were tested in a linear viscoelastic tension/compression regime afterwards. Results showed that the dynamic stiffness was decreased at low loads. Nucleus pulposus GAG content was shown to be related to the neutral zone properties in the tensioncompression cyclic tests. However, the tension and compression extremes of the load displacement curve were not. This shows that a degenerate nucleus produces hypermobility in addition to low pressures. Such distortion in load sharing leads to the development of hoop stresses in the anulus that resist compressive loads. ${ }^{72,73}$

Kim et al ${ }^{74-76}$ used a rabbit degenerative disc model by 18 -gauge needle puncture of the disc to investigate changes in dynamic viscoelastic properties of the whole disc associated with the disc degeneration. In this model, the proteoglycan content decreased and collagen content increased 4 weeks after puncture. The dynamic viscoelastic test showed a decrease in elastic and viscous properties in the punctured disc (Figure 1). The correlation study showed that the proteoglycan content positively correlated with the elastic and viscous mechanical properties and height of the disc; however, there was no correlation with the collagen content. These results suggest that the proteoglycan is a governing factor for viscoelastic properties and structural properties of the disc.

Using the same rabbit degenerative disc model and the dynamic viscoelastic testing method, Miyamoto et $a l^{77}$ investigated effects of OP-1 injection in the lumbar disc on biomechanical and biochemical restoration of the disc. In this study, a significant increase in wet weight and proteoglycan content was observed in both nucleus pulposus and anulus fibrosus tissues of the OP-1-injected discs, compared with the lactose injected control discs, whereas an increase in collagen content was observed only in the nucleus pulposus. These results suggested that an increased proteoglycan content, induced by the injection of OP-1, resulted in tissue hydration in both the nucleus pulposus and anulus fibrosus. The results of the dynamic viscoelastic test showed that the elastic modulus has a significant positive correlation with the proteoglycan content in the nucleus pulposus and the proteoglycan and collagen content in the anulus fibrosus. Similarly, the viscous modulus was shown to have a significant positive correlation with the proteoglycan content in the nucleus pulposus and the proteoglycan and collagen content in the anulus fibrosus.

\section{Instability of the Motion Segment Associated with Intervertebral Disc Degeneration}

As disc degeneration progresses, structural failure of the disc is manifested by tears and clefts in the anulus fibrosus. These material disruptions occur in different directions and are the result of a variety of influencing factors, including altered loading of the disc. Potential relationships between osteophytes and peripheral tears were first reported by Schmorl and 
Junghanns, ${ }^{78}$ and also highlighted the fact that because of the tears, segmental instability would be affected. Farfan ${ }^{79}$ and Kirkaldy-Willis ${ }^{80}$ concluded that tears were by-products of torsional stresses, implicating them as initiators of the failure of other disc components in the disc degeneration cascade.

Disc fissures have been classified in three categories, depending on their morphology and anatomical position in the disc: a) peripheral tears or rim lesions, parallel to the endplates and exhibiting normally separation of the disc from the subchondral bone of the vertebral body, which with time developed b) circumferential tears that present evidence of delamination as a failure mode. Finally, c) radial tears, as it name implies, propagate in a direction perpendicular to an imaginary axis of the disc (if it is considered as a flat cylinder), which usually lead to disc herniations and expulsion of nucleus material. The literature shows few reports that address the crack propagation phenomena involved in disc tears, as it is common to report only the resulting condition (ruptured anulus, herniated disc). ${ }^{38,81,82}$ Many of the models consider the anulus as a bulk material, but recently, more advanced models have incorporated annular layers ${ }^{83}$ and implemented permeability and porosity ${ }^{84-87}$, as well as the disc's osmo-viscoelastic properties ${ }^{88,89}$ The interlamellar structures have been deemed especially sensitive to shear stresses, ${ }^{25,90,91}$ and the literature is lacking reports of their allegedly weaker mechanical properties. They are thought to play a predominant role when destructive processes such as delamination occur as part of herniation, as it has been attempted in analytical models of the disc ${ }^{92}$, of anulus fibrosus tissue ${ }^{93}$ and of individual lamellae. ${ }^{94}$ Schollum et al ${ }^{67,95}$ have been one of the few who recently analyzed in detail the interface between annular lamellae in an ovine model by subjecting thin slices of immature and mature anulus fibrosus tissue to micro-tensile tests. While their studies was mostly attempting to describe the architecture of the interlamellar interface, important differences in the response to tensile forces were shown between young and old tissue, with the older tissue exhibiting a more ordered and uniform lamellar separation than the young tissue; however the authors did not report elastic properties.

Fujiwara et $_{\text {al }}{ }^{7,96}$ studied the effect of disc degeneration graded by MRI on the segmental motion of the lumbar spine using a total of 106 motion segments obtained from 44 cadaveric lumbar spines taken from 18 females and 25 males with a mean age of 69 years. The investigators found that segmental motion increased with increasing severity of disc degeneration to grade 4 but decreased when the disc degeneration advanced up to grade 5 . Such segmental motion changes were much greater in axial rotation when compared with those in lateral bending, flexion and extension, demonstrating the importance of torsional instability in diagnosing spinal instability. The results of these studies are important for understanding the kinematic property changes in relation to the types or grades of disc degeneration. The results were consistent with the previous reports and the concept of three stages of spinal degeneration: dysfunction, instability and restabilization proposed by Kirkaldy-Willis and Farfan. ${ }^{97}$

\section{Instability of the Lumbar Spine Associated with Intervertebral Disc Degeneration}

Segmental instability of the lumbar spine is frequently considered a cause of LBP, but instability of the spine is poorly defined and understood. ${ }^{97-105}$ The basic concept of spinal instability is that excessive motion beyond normal constraints causes either compression or stretching of the neural elements or causes abnormal deformations of ligaments, joint capsules, annular fibers, or endplates, which are known to have a significant number of nociceptors. Even though several studies have indicated that excessive motion on flexion/ extension radiographs is associated with LBP or degenerative disc disease, ${ }^{106,107}$ other studies cite decreased motion in patients with degenerative changes and such pain. ${ }^{108,109}$ 
Lumbar segmental instability may be associated with a spectrum of clinical manifestations of degenerative changes in the intervertebral disc. ${ }^{97,110-114}$ Intervertebral disc degeneration has been studied using MR imaging, and grades of degeneration have been reported. ${ }^{111-118}$ The relationship between the types (or grades) of disc degeneration and kinematic characteristics of the motion segment has been studied using cadaveric spinal motion segments. ${ }^{96,119-123}$ Despite some variation in results, likely because different loading conditions and methods of grading degenerative disc changes were used, the overall results of these studies indicate that the biomechanical characteristics of the motion segment can become altered significantly when degenerative changes develop in the intervertebral disc.

\section{In vivo measurement of lumbar segmental movement}

There have been numerous in vivo studies on segmental instability of the lumbar spine in which dynamic flexion/extension radiographs were used. ${ }^{108,124-133}$ However, these dynamic radiographic techniques have been found to be inaccurate. ${ }^{134,135}$ The errors associated with sagittal plane translational motion measurement reported in the literature range from 1 to 4 $\mathrm{mm}^{134,136}$ or $3 \%$ to $15 \%$ of the vertebral depth. ${ }^{137-139}$ Schaffer et al ${ }^{135}$ reported surprisingly high false-positive and false-negative rates (i.e., normal translations are categorized outside of the normal range and vice versa) with significant differences between measurement methods despite very high reliability across radiographic quality, raters, and measurement. More sophisticated techniques such as biplanar stereoradiography, ${ }^{140-145}$ centrode pattern analysis, 100,137,146-156 and traction-compression radiography, ${ }^{138,157}$ have been introduced but have not been widely accepted. More accurate methods involve invasive techniques by inserting metal beads or spinous process wire to determine three-dimension (3-D) motion. ${ }^{158-160}$ However, because these methods are invasive, they are not appropriate for routine use in clinical practice as well as for in vivo human studies. Studies on segmental instability also have been limited by other factors in addition to these problems associated with accurate measurement of segmental motion in vivo. For example, the range of motion measured in most of these studies is affected by the variability in voluntary efforts that the subject applies at the time of examination and also can be limited because of pain.

Other 2-D imaging methods for measuring axial rotation, as opposed to flexion/extension, have involved MR imaging of subjects in various rotated positions. ${ }^{161,162}$ While these studies were non-invasive and controlled for voluntary motions, they could only determine changes in segmental motion around one axis. It has been suggested that coupled motions could play an important role in determining spinal instability. To measure these coupled motions, studies have been conducted to measure 3-D motions in vivo. More invasive techniques involve inserting wires into the spinous process of subjects to determine 3-D motion. ${ }^{163}$ While this method has proven more accurate than radiographs, its invasive nature limits its wide spread clinical use. Other studies have used biplanar radiography, where the radiograms of the spine were taken from two directions simultaneously and 3-D motions are calculated by the positions of anatomical landmarks in corresponding images. ${ }^{142,164-167}$ There has been some concern about the accuracy in determining anatomical landmarks for biplanar radiography, as well as a lack of equipment for this method in typical clinical settings.

To overcome some of these limitations to 3-D motion measurement, Lim et al ${ }^{168}$ developed a 3-D imaging technique using dynamic computed tomography (CT) to determine 6 degreeof-freedom (3 rotations and 3 translations) transformation of individual cadaveric cervical vertebrae during motion by tracking eigenvectors of the individual vertebrae. The authors illustrated that accurate measurements $\left( \pm 1 \mathrm{~mm}\right.$ and $\left.\pm 1^{\circ}\right)$ can be made using CT in vitro. The research group expanded on this technique to measure vertebral segmental movements in human lumbar spines in vivo (Figure 2). Although this method was able to determine the rotations and translations of the lumbar vertebrae during motion in vivo, it was limited in 
determining transformation of the sacrum because an entire 3-D CT model of a sacrum is difficult to obtain clinically and the eigenvector analysis using a partial sacrum 3-D model caused an error of the measurement of the segmental motion at L5-S1. The same research group developed another method to determine transformation of individual vertebrae including the sacrum during motion using the 3-D CT model and a Volume-Merge method (Figure 3). ${ }^{169,170}$ This method can determine the rotations and translations during motion even if the 3-D geometry of the bone is incomplete, as in the case of the sacrum (an assumption of the bone as a rigid body still holds) at each position. Thus, it is able to determine the transformation of the incomplete sacrum 3-D CT model with an accuracy of less than $0.1 \mathrm{~mm}$ in translation and $0.2^{\circ}$ in rotation.

\section{Relationship between instability and disc degeneration}

Most patients with segmental instability have disc degeneration, but the relationship between instability and degeneration is not clear. Takeuchi et al ${ }^{171}$ presented a study using MR images in which T1 relaxation time was decreased in degenerative discs and the energy dissipated to axial loading was linearly correlated with $\mathrm{T} 1$ relaxation time. The authors attempted to correlate the intrinsic biomechanical properties of the disc with MR imaging findings, but no information could be derived about the segmental motion characteristics from this study. Toyone et al ${ }^{172}$ reported that bone marrow adjacent to the disc in patients with symptomatic lumbar segmental instability, defined by flexion more than $5^{\circ}$ and dynamic anterior-posterior translation more than $3 \mathrm{~mm}$, had decreased signals on $\mathrm{T} 1$ weighted spin-echo MR images or Modic type I changes. Inaccurate flexion/extension radiographs of patients were used in this study by Toyone et al ${ }^{172}$ and pathogenesis of the osseous changes with disc degeneration is not known.

Results of the in vitro studies of segmental motion characteristics and disc degeneration done by Fujiwara et al ${ }^{96}$ demonstrated that torsional motion was most significantly affected by the degenerative changes in disc and facet joints. In addition, some investigators advocate the importance of torsional loads and stability on the injuries and degeneration of the motion segments. ${ }^{17-178}$ Torsional instability in relation to the degenerative changes in the disc had been investigated in vivo using the aforementioned in vivo 3-D measurement technique. ${ }^{168}$ The investigators found that a relationship exists between the severity of IVD degeneration and increases in the torsional movement in vivo, which was previously demonstrated only in the cadaveric studies. ${ }^{169,170}$

\section{Summary}

A decrease in proteoglycan content and an increased collagen fiber associated with degeneration contribute changes in material properties of nucleus pulposus from a fluid-like material to a solid-like material. Changes in material properties of the anulus fibrosus tissue are also affected by water content, which is a direct consequence of proteoglycan content. Degenerative structural changes of the entire disc are well documented as are the changes in its viscoelastic properties. Decrease in proteoglycan content in the nucleus pulposus is also considered as a governing factor affecting the dynamic viscoelastic properties of the entire disc. The highest correlation between the instability and the severity of the disc degeneration in torsion, among different loading directions, indicates that the fissures in the anulus fibrosus contribute the instability. This result agrees with the concept of "degenerative cascade" proposed by Kirkaldy-Willis. Increased segmental movement with disc degeneration up to grade 4 has also been measured in vivo. Further investigation will still be needed to confirm whether LBP is associated with increased segmental motion. To this end, current progress made on image analysis techniques using clinical imaging modalities will be a powerful tool to investigate this challenging problem. 


\section{Acknowledgments}

This work was supported by NIH grant P01 AR48152

\section{References}

1. Adams MA, Dolan P, McNally DS. The internal mechanical functioning of intervertebral discs and articular cartilage, and its relevance to matrix biology. Matrix Biol. 2009; 28:384. [PubMed: 19586615]

2. Hadjipavlou AG, Tzermiadianos MN, Bogduk N, et al. The pathophysiology of disc degeneration: a critical review. J Bone Joint Surg Br. 2008; 90:1261. [PubMed: 18827232]

3. Roughley PJ. Biology of intervertebral disc aging and degeneration: involvement of the extracellular matrix. Spine (Phila Pa 1976). 2004; 29:2691. [PubMed: 15564918]

4. Yoon ST. The potential of gene therapy for the treatment of disc degeneration. Orthop Clin North Am. 2004; 35:95. [PubMed: 15062722]

5. Hukins DWL, Meakin JR. Relationship Between Structure and Mechanical Function of the Tissues of the Intervertebral Joint. Amer Zool. 2000; 40:42.

6. Antoniou J, Steffen T, Nelson F, et al. The human lumbar intervertebral disc: evidence for changes in the biosynthesis and denaturation of the extracellular matrix with growth, maturation, ageing, and degeneration. J Clin Invest. 1996; 98:996. [PubMed: 8770872]

7. Podichetty VK. The aging spine: the role of inflammatory mediators in intervertebral disc degeneration. Cell Mol Biol (Noisy-le-grand). 2007; 53:4. [PubMed: 17543240]

8. Urban JPG, Roberts S, Ralphs J. The Nucleus of the Intervertebral Disc from Development to Degeneration. Amer Zool. 2000; 40:53.

9. Coventry MB, Ghormley RK, Kernohan JW. The Invertertebral Disc: Its Microscopic Anatomy and Pathology: Part I Anatomy, Development, and Physiology. J Bone Joint Surg Am. 1945; 27:105.

10. Haefeli M, Kalberer F, Saegesser D, et al. The course of macroscopic degeneration in the human lumbar intervertebral disc. Spine (Phila Pa 1976). 2006; 31:1522. [PubMed: 16778683]

11. Bibby SR, Jones DA, Lee RB, et al. The pathophysiology of the intervertebral disc. Joint Bone Spine. 2001; 68:537. [PubMed: 11808995]

12. Murakami H, Yoon TS, Attallah-Wasif ES, et al. Quantitative differences in intervertebral discmatrix composition with age-related degeneration. Med Biol Eng Comput. 2010; 48:469. [PubMed: 20151333]

13. McNally DS, Adams MA. Internal intervertebral disc mechanics as revealed by stress profilometry. Spine (Phila Pa 1976). 1992; 17:66. [PubMed: 1536017]

14. McNally DS, Adams MA, Goodship AE. Development and validation of a new transducer for intradiscal pressure measurement. J Biomed Eng. 1992; 14:495. [PubMed: 1434572]

15. McNally DS, Shackleford IM, Goodship AE, et al. In vivo stress measurement can predict pain on discography. Spine (Phila Pa 1976). 1996; 21:2580. [PubMed: 8961445]

16. Adams MA, McNally DS, Dolan P. 'Stress' distributions inside intervertebral discs. The effects of age and degeneration. J Bone Joint Surg Br. 1996; 78:965. [PubMed: 8951017]

17. Iatridis JC, Weidenbaum M, Setton LA, et al. Is the nucleus pulposus a solid or a fluid? Mechanical behaviors of the nucleus pulposus of the human intervertebral disc. Spine (Phila $\mathrm{Pa}$ 1976). 1996; 21:1174. [PubMed: 8727192]

18. Nachemson A, Morris J. Lumbar discometry. Lumbar intradiscal pressure measurements in vivo. Lancet. 1963; 1:1140. [PubMed: 13937020]

19. Nachemson A, Morris JM. In Vivo Measurements Of Intradiscal Pressure. Discometry, A Method For The Determination Of Pressure In The Lower Lumbar Discs. J Bone Joint Surg Am. 1964; 46:1077. [PubMed: 14193834]

20. Nachemson AL. Disc pressure measurements. Spine (Phila Pa 1976). 1981; 6:93. [PubMed: 7209680]

21. Nachemson AL. Intradiscal pressure. J Neurosurg. 1995; 82:1095. [PubMed: 7760187] 
22. Adams MA, Freeman BJ, Morrison HP, et al. Mechanical initiation of intervertebral disc degeneration. Spine (Phila Pa 1976). 2000; 25:1625. [PubMed: 10870137]

23. McNally DS, Adams MA, Goodship AE. Can intervertebral disc prolapse be predicted by disc mechanics? Spine (Phila Pa 1976). 1993; 18:1525. [PubMed: 8235825]

24. Buckwalter JA. Aging and degeneration of the human intervertebral disc. Spine (Phila Pa 1976). 1995; 20:1307. [PubMed: 7660243]

25. Iatridis JC, Setton LA, Weidenbaum M, et al. Alterations in the mechanical behavior of the human lumbar nucleus pulposus with degeneration and aging. J Orthop Res. 1997; 15:318. [PubMed: 9167638]

26. Stokes IA, Iatridis JC. Mechanical conditions that accelerate intervertebral disc degeneration: overload versus immobilization. Spine (Phila Pa 1976). 2004; 29:2724. [PubMed: 15564921]

27. Urban JP, McMullin JF. Swelling pressure of the lumbar intervertebral discs: influence of age, spinal level, composition, and degeneration. Spine (Phila Pa 1976). 1988; 13:179. [PubMed: 3406838]

28. Johannessen W, Elliott DM. Effects of degeneration on the biphasic material properties of human nucleus pulposus in confined compression. Spine (Phila Pa 1976). 2005; 30:E724. [PubMed: 16371889]

29. Nachemson A. Lumbar intradiscal pressure. Experimental studies on post-mortem material. Acta Orthop Scand Suppl. 1960; 43:1. [PubMed: 14425680]

30. Smith LJ, Byers S, Costi JJ, et al. Elastic fibers enhance the mechanical integrity of the human lumbar anulus fibrosus in the radial direction. Ann Biomed Eng. 2008; 36:214. [PubMed: 18066662]

31. Smith LJ, Fazzalari NL. The elastic fibre network of the human lumbar anulus fibrosus: architecture, mechanical function and potential role in the progression of intervertebral disc degeneration. Eur Spine J. 2009; 18:439. [PubMed: 19263091]

32. Skaggs DL, Weidenbaum M, Iatridis JC, et al. Regional variation in tensile properties and biochemical composition of the human lumbar anulus fibrosus. Spine (Phila Pa 1976). 1994; 19:1310. [PubMed: 8066509]

33. Acaroglu ER, Iatridis JC, Setton LA, et al. Degeneration and aging affect the tensile behavior of human lumbar anulus fibrosus. Spine (Phila Pa 1976). 1995; 20:2690. [PubMed: 8747247]

34. Ebara S, Iatridis JC, Setton LA, et al. Tensile properties of nondegenerate human lumbar anulus fibrosus. Spine (Phila Pa 1976). 1996; 21:452. [PubMed: 8658249]

35. Galante JO. Tensile properties of the human lumbar anulus fibrosus. Acta Orthop Scand:Suppl. 1967; 100:1.

36. Wu HC, Yao RF. Mechanical behavior of the human anulus fibrosus. J Biomech. 1976; 9:1. [PubMed: 1249075]

37. Schollum ML, Robertson PA, Broom ND. How age influences unravelling morphology of annular lamellae - a study of interfibre cohesivity in the lumbar disc. J Anat. 2010; 216:310. [PubMed: 20447247]

38. Schollum ML, Robertson PA, Broom ND. ISSLS prize winner: microstructure and mechanical disruption of the lumbar disc anulus: part I: a microscopic investigation of the translamellar bridging network. Spine (Phila Pa 1976). 2008; 33:2702. [PubMed: 19002075]

39. Guerin HL, Elliott DM. Quantifying the contributions of structure to anulus fibrosus mechanical function using a nonlinear, anisotropic, hyperelastic model. J Orthop Res. 2007; 25:508. [PubMed: 17149747]

40. Wagner DR, Lotz JC. Theoretical model and experimental results for the nonlinear elastic behavior of human anulus fibrosus. J Orthop Res. 2004; 22:901. [PubMed: 15183453]

41. Wren TA, Carter DR. A microstructural model for the tensile constitutive and failure behavior of soft skeletal connective tissues. J Biomech Eng. 1998; 120:55. [PubMed: 9675681]

42. Elliott DM, Narmoneva DA, Setton LA. Direct measurement of the Poisson's ratio of human patella cartilage in tension. J Biomech Eng. 2002; 124:223. [PubMed: 12002132]

43. Soltz MA, Ateshian GA. A Conewise Linear Elasticity mixture model for the analysis of tensioncompression nonlinearity in articular cartilage. J Biomech Eng. 2000; 122:576. [PubMed: 11192377] 
44. Woo SL, Simon BR, Kuei SC, et al. Quasi-linear viscoelastic properties of normal articular cartilage. J Biomech Eng. 1980; 102:85. [PubMed: 7412243]

45. Li LP, Soulhat J, Buschmann MD, et al. Nonlinear analysis of cartilage in unconfined ramp compression using a fibril reinforced poroelastic model. Clin Biomech (Bristol, Avon). 1999; 14:673.

46. Huang CY, Mow VC, Ateshian GA. The role of flow-independent viscoelasticity in the biphasic tensile and compressive responses of articular cartilage. J Biomech Eng. 2001; 123:410. [PubMed: 11601725]

47. Guerin HA, Elliott DM. Degeneration affects the fiber reorientation of human anulus fibrosus under tensile load. J Biomech. 2006; 39:1410. [PubMed: 15950233]

48. O'Connell GD, Guerin HL, Elliott DM. Theoretical and uniaxial experimental evaluation of human anulus fibrosus degeneration. J Biomech Eng. 2009; 131:111007. [PubMed: 20353258]

49. Sen, S.; Boxberger, JI.; Schroeder, Y., et al. Effect of degeneration on the dynamic viscoelastic properties of human anulus fibrosus in tension. Proceedings of the ASME 2008 Summer Bioengineering Conference; Marco Island, FL.

50. Gu WY, Mao XG, Foster RJ, et al. The anisotropic hydraulic permeability of human lumbar anulus fibrosus. Influence of age, degeneration, direction, and water content. Spine (Phila Pa 1976). 1999; 24:2449. [PubMed: 10626306]

51. Natarajan RN, Williams JR, Andersson GB. Modeling changes in intervertebral disc mechanics with degeneration. J Bone Joint Surg Am. 2006; 88 Suppl 2:36. [PubMed: 16595441]

52. Adams MA, Dolan P, Hutton WC. The lumbar spine in backward bending. Spine (Phila Pa 1976). 1988; 13:1019. [PubMed: 3206295]

53. Hirsch C. The reaction of intervertebral discs to compression forces. J Bone Joint Surg Am. 1955; 37-A:1188. [PubMed: 13271464]

54. White, AA.; Panjabi, M. Clinical Biomechanics of the Spine. Philadelphia: Lippincott Williams \& Wilkins; 1990.

55. Reuber M, Schultz A, Denis F, et al. Bulging of lumbar intervertebral disks. J Biomech Eng. 1982; 104:187. [PubMed: 7120942]

56. Nachemson A. The load on lumbar disks in different positions of the body. Clin Orthop Relat Res. 1966; 45:107. [PubMed: 5937361]

57. Nachemson A. Mechanical stresses on lumbar disks. Curr Pract Orthop Surg. 1966; 3:208. [PubMed: 5339244]

58. Wilke HJ, Neef P, Caimi M, et al. New in vivo measurements of pressures in the intervertebral disc in daily life. Spine (Phila Pa 1976). 1999; 24:755. [PubMed: 10222525]

59. Schultz AB, Andersson GB. Analysis of loads on the lumbar spine. Spine (Phila Pa 1976). 1981; 6:76. [PubMed: 7209677]

60. Schultz AB, Andersson GB, Haderspeck K, et al. Analysis and measurement of lumbar trunk loads in tasks involving bends and twists. J Biomech. 1982; 15:669. [PubMed: 7174699]

61. Andersson GB, Schultz AB. Effects of fluid injection on mechanical properties of intervertebral discs. J Biomech. 1979; 12:453. [PubMed: 457699]

62. Elliott DM, Yerramalli CS, Beckstein JC, et al. The effect of relative needle diameter in puncture and sham injection animal models of degeneration. Spine (Phila Pa 1976). 2008; 33:588. [PubMed: 18344851]

63. Hsieh AH, Hwang D, Ryan DA, et al. Degenerative anular changes induced by puncture are associated with insufficiency of disc biomechanical function. Spine (Phila Pa 1976). 2009; 34:998. [PubMed: 19404174]

64. Wang JL, Tsai YC, Wang YH. The leakage pathway and effect of needle gauge on degree of disc injury post anular puncture: a comparative study using aged human and adolescent porcine discs. Spine (Phila Pa 1976). 2007; 32:1809. [PubMed: 17762287]

65. Korecki CL, Kuo CK, Tuan RS, et al. Intervertebral disc cell response to dynamic compression is age and frequency dependent. J Orthop Res. 2009; 27:800. [PubMed: 19058142]

66. Korecki CL, MacLean JJ, Iatridis JC. Characterization of an in vitro intervertebral disc organ culture system. Eur Spine J. 2007; 16:1029. [PubMed: 17629763] 
67. Schollum ML, Appleyard RC, Little CB, et al. A detailed microscopic examination of alterations in normal anular structure induced by mechanical destabilization in an ovine model of disc degeneration. Spine (Phila Pa 1976). 2010; 35:1965. [PubMed: 20959777]

68. Wuertz K, Godburn K, MacLean JJ, et al. In vivo remodeling of intervertebral discs in response to short- and long-term dynamic compression. J Orthop Res. 2009; 27:1235. [PubMed: 19274755]

69. Korecki CL, Costi JJ, Iatridis JC. Needle puncture injury affects intervertebral disc mechanics and biology in an organ culture model. Spine (Phila Pa 1976). 2008; 33:235. [PubMed: 18303454]

70. MacLean JJ, Roughley PJ, Monsey RD, et al. In vivo intervertebral disc remodeling: kinetics of mRNA expression in response to a single loading event. J Orthop Res. 2008; 26:579. [PubMed: 18176944]

71. Johannessen W, Vresilovic EJ, Wright AC, et al. Intervertebral disc mechanics are restored following cyclic loading and unloaded recovery. Ann Biomed Eng. 2004; 32:70. [PubMed: 14964723]

72. Boxberger JI, Orlansky AS, Sen S, et al. Reduced nucleus pulposus glycosaminoglycan content alters intervertebral disc dynamic viscoelastic mechanics. J Biomech. 2009; 42:1941. [PubMed: 19539936]

73. Boxberger JI, Sen S, Yerramalli CS, et al. Nucleus pulposus glycosaminoglycan content is correlated with axial mechanics in rat lumbar motion segments. J Orthop Res. 2006; 24:1906. [PubMed: 16865712]

74. Kim J, An H, Masuda K, et al. Dynamic viscoelastic properties of rabbit lumbar discs. Trans Orthop Res Soc. : 1280 .

75. Kim, JG.; An, HS.; Masuda, K., et al. Dissimilarity in dynamic viscoelastic properties of lumbar disc levels. New York, NY: The International Society for the Study of the Lumbar Spine;

76. Kim, JG.; Miyamoto, K.; Masuda, K., et al. Correlations among biomechanical, biochemical and structural properties of the degenerated intervertebral disc. 52nd Annual Meeting of the Orthopaedic Research Society; Chicago, IL. p. 49

77. Miyamoto K, Masuda K, Kim JG, et al. Intradiscal injections of osteogenic protein-1 restore the viscoelastic properties of degenerated intervertebral discs. Spine J. 2006; 6:692. [PubMed: 17088200]

78. Schmorl, G.; Junghanns, H. The Human Spine in Health and Disease. New York and London: Grunne and Stratton; 1971.

79. Farfan, HF. Mechanical Disorders of the Low Back. Philadelphia: Lea \& Febiger; 1973.

80. Kirkaldy-Willis, WH. The Pathology and Pathogenesis of Low Back Pain. In: Kirkaldy-Willis, WH., editor. Managing Low Back Pain. Churchill Livingstone: Managing low back pain; 1983. p. 23

81. Tampier C, Drake JD, Callaghan JP, et al. Progressive disc herniation: an investigation of the mechanism using radiologic, histochemical, and microscopic dissection techniques on a porcine model. Spine (Phila Pa 1976). 2007; 32:2869. [PubMed: 18246010]

82. Veres SP, Robertson PA, Broom ND. ISSLS prize winner: microstructure and mechanical disruption of the lumbar disc anulus: part II: how the anulus fails under hydrostatic pressure. Spine (Phila Pa 1976). 2008; 33:2711. [PubMed: 19002077]

83. Natarajan, RN.; Lundberg, HJ.; Oegema, T., et al. A Novel Multilayered Annular Model to Predict Delamination in a Lumbar Intervertebral Disc. Proceedings of the ASME 2009 Summer Bioengineering Conference, Resort at Squaw Creek; Lake Tahoe, CA, USA.

84. Fagan AB, Sarvestani G, Moore RJ, et al. Innervation of anulus tears: an experimental animal study. Spine (Phila Pa 1976). 2010; 35:1200. [PubMed: 20445481]

85. Galbusera F, Schmidt H, Neidlinger-Wilke C, et al. The mechanical response of the lumbar spine to different combinations of disc degenerative changes investigated using randomized poroelastic finite element models. Eur Spine J. 2010 In Press.

86. Schmidt H, Shirazi-Adl A, Galbusera F, et al. Response analysis of the lumbar spine during regular daily activities--a finite element analysis. J Biomech. 2010; 43:1849. [PubMed: 20394933]

87. Williams JR, Natarajan RN, Andersson GB. Inclusion of regional poroelastic material properties better predicts biomechanical behavior of lumbar discs subjected to dynamic loading. J Biomech. 2007; 40:1981. [PubMed: 17156786] 
88. Schroeder Y, Elliott DM, Wilson W, et al. Experimental and model determination of human intervertebral disc osmoviscoelasticity. J Orthop Res. 2008; 26:1141. [PubMed: 18327799]

89. Schroeder Y, Huyghe JM, van Donkelaar CC, et al. A biochemical/biophysical 3D FE intervertebral disc model. Biomech Model Mechanobiol. 2010; 9:641. [PubMed: 20229171]

90. Costi JJ, Stokes IA, Gardner-Morse M, et al. Direct measurement of intervertebral disc maximum shear strain in six degrees of freedom: motions that place disc tissue at risk of injury. J Biomech. 2007; 40:2457. [PubMed: 17198708]

91. Iatridis JC, Mente PL, Stokes IA, et al. Compression-induced changes in intervertebral disc properties in a rat tail model. Spine (Phila Pa 1976). 1999; 24:996. [PubMed: 10332792]

92. Goel VK, Monroe BT, Gilbertson LG, et al. Interlaminar shear stresses and laminae separation in a disc. Finite element analysis of the L3-L4 motion segment subjected to axial compressive loads. Spine (Phila Pa 1976). 1995; 20:689. [PubMed: 7604345]

93. Elliott DM, Setton LA. Anisotropic and inhomogeneous tensile behavior of the human anulus fibrosus: experimental measurement and material model predictions. J Biomech Eng. 2001; 123:256. [PubMed: 11476369]

94. Holzapfel GA, Schulze-Bauer CA, Feigl G, et al. Single lamellar mechanics of the human lumbar anulus fibrosus. Biomech Model Mechanobiol. 2005; 3:125. [PubMed: 15778871]

95. Schollum ML, Robertson PA, Broom ND. A microstructural investigation of intervertebral disc lamellar connectivity: detailed analysis of the translamellar bridges. J Anat. 2009; 214:805. [PubMed: 19538627]

96. Fujiwara A, Lim TH, An HS, et al. The effect of disc degeneration and facet joint osteoarthritis on the segmental flexibility of the lumbar spine. Spine (Phila Pa 1976). 2000; 25:3036. [PubMed: 11145815]

97. Kirkaldy-Willis WH, Farfan HF. Instability of the lumbar spine. Clin Orthop Relat Res. 1982:110. [PubMed: 6210480]

98. Farfan HF, Gracovetsky S. The nature of instability. Spine (Phila Pa 1976). 1984; 9:714. [PubMed: 6505842]

99. Frymoyer JW, Newberg A, Pope MH, et al. Spine radiographs in patients with low-back pain. An epidemiological study in men. J Bone Joint Surg Am. 1984; 66:1048. [PubMed: 6237110]

100. Gertzbein SD, Seligman J, Holtby R, et al. Centrode patterns and segmental instability in degenerative disc disease. Spine (Phila Pa 1976). 1985; 10:257. [PubMed: 3992346]

101. Morgan FP, King T. Primary instability of lumbar vertebrae as a common cause of low back pain. J Bone Joint Surg Br. 1957; 39-B:6. [PubMed: 13405944]

102. Nachemson A. Lumbar spine instability. A critical update and symposium summary. Spine (Phila Pa 1976). 1985; 10:290. [PubMed: 3992351]

103. Panjabi, M. Low back pain and spinal instability. In: Weinstein, J.; Gordon, SL., editors. Low Back Pain: A Scientific and Clinical Overview. Rosemont: American Academy of Orthopedic Surgeons; 1996. p. 367

104. Panjabi, MM.; Kaigle, AM.; Pope, MH. Degeneration, injury, and spinal instability. In: Wiesel, SW.; Weinstein, JN.; Herkowitz, H., et al., editors. The Lumbar Spine. Philadelphia: W.B. Saunders Company; 1996. p. 203

105. Stokes IA, Frymoyer JW. Segmental motion and instability. Spine (Phila Pa 1976). 1987; 12:688. [PubMed: 2961083]

106. Hayes MA, Howard TC, Gruel CR, et al. Roentgenographic evaluation of lumbar spine flexionextension in asymptomatic individuals. Spine (Phila Pa 1976). 1989; 14:327. [PubMed: 2711247]

107. Knuttson F. The instability associated with disc degeneration in the lumbar spine. Acta Radiol. 1944; 25:593.

108. Dvorak J, Panjabi MM, Grob D, et al. Clinical validation of functional flexion/extension radiographs of the cervical spine. Spine (Phila Pa 1976). 1993; 18:120. [PubMed: 8434312]

109. Gracovetsky S, Newman N, Pawlowsky M, et al. A database for estimating normal spinal motion derived from noninvasive measurements. Spine (Phila Pa 1976). 1995; 20:1036. [PubMed: 7631233] 
110. Boden SD, Davis DO, Dina TS, et al. Abnormal magnetic-resonance scans of the lumbar spine in asymptomatic subjects. A prospective investigation. J Bone Joint Surg Am. 1990; 72:403. [PubMed: 2312537]

111. Modic MT, Masaryk TJ, Ross JS, et al. Imaging of degenerative disk disease. Radiology. 1988; 168:177. [PubMed: 3289089]

112. Modic MT, Masaryk TJ, Weinstein MA. Magnetic resonance imaging of the spine. Magn Reson Annu. 1986:37. [PubMed: 3079343]

113. Modic MT, Ross JS. Magnetic resonance imaging in the evaluation of low back pain. Orthop Clin North Am. 1991; 22:283. [PubMed: 1826552]

114. Modic MT, Ross JS. Lumbar degenerative disk disease. Radiology. 2007; 245:43. [PubMed: 17885180]

115. Modic MT. Advances in spinal imaging. Clin Neurosurg. 1992; 38:97. [PubMed: 1537209]

116. Nowicki BH, Haughton VM. Neural foraminal ligaments of the lumbar spine: appearance at CT and MR imaging. Radiology. 1992; 183:257. [PubMed: 1549683]

117. Pfirrmann CW, Metzdorf A, Zanetti M, et al. Magnetic resonance classification of lumbar intervertebral disc degeneration. Spine (Phila Pa 1976). 2001; 26:1873. [PubMed: 11568697]

118. Thompson JP, Pearce RH, Schechter MT, et al. Preliminary evaluation of a scheme for grading the gross morphology of the human intervertebral disc. Spine (Phila Pa 1976). 1990; 15:411. [PubMed: 2363069]

119. Haughton VM, Schmidt TA, Keele K, et al. Flexibility of lumbar spinal motion segments correlated to type of tears in the anulus fibrosus. J Neurosurg. 2000; 92:81. [PubMed: 10616062]

120. Mimura M, Panjabi MM, Oxland TR, et al. Disc degeneration affects the multidirectional flexibility of the lumbar spine. Spine (Phila Pa 1976). 1994; 19:1371. [PubMed: 8066518]

121. Nachemson AL, Schultz AB, Berkson MH. Mechanical properties of human lumbar spine motion segments. Influence of age, sex, disc level, and degeneration. Spine (Phila Pa 1976). 1979; 4:1. [PubMed: 432710]

122. Nowicki BH, Yu S, Reinartz J, et al. Effect of axial loading on neural foramina and nerve roots in the lumbar spine. Radiology. 1990; 176:433. [PubMed: 2367657]

123. Schmidt TA, An HS, Lim TH, et al. The stiffness of lumbar spinal motion segments with a highintensity zone in the anulus fibrosus. Spine (Phila Pa 1976). 1998; 23:2167. [PubMed: 9802156]

124. Boden SD, Wiesel SW. Lumbosacral segmental motion in normal individuals. Have we been measuring instability properly? Spine (Phila Pa 1976). 1990; 15:571. [PubMed: 2402698]

125. Boxall D, Bradford DS, Winter RB, et al. Management of severe spondylolisthesis in children and adolescents. J Bone Joint Surg Am. 1979; 61:479. [PubMed: 438234]

126. Dupuis PR, Yong-Hing K, Cassidy JD, et al. Radiologic diagnosis of degenerative lumbar spinal instability. Spine (Phila Pa 1976). 1985; 10:262. [PubMed: 3992347]

127. Dvorak J, Panjabi MM, Chang DG, et al. Functional radiographic diagnosis of the lumbar spine. Flexion-extension and lateral bending. Spine (Phila Pa 1976). 1991; 16:562. [PubMed: 2052999]

128. Dvorak J, Panjabi MM, Novotny JE, et al. Clinical validation of functional flexion-extension roentgenograms of the lumbar spine. Spine (Phila Pa 1976). 1991; 16:943. [PubMed: 1835156]

129. Lysell E. Motion in the cervical spine. An experimental study on autopsy specimens. Acta Orthop Scand. 1969 Suppl $1231+$

130. Penning L. Normal movements of the cervical spine. AJR Am J Roentgenol. 1978; 130:317. [PubMed: 414586]

131. Posner I, White AA 3rd, Edwards WT, et al. A biomechanical analysis of the clinical stability of the lumbar and lumbosacral spine. Spine (Phila Pa 1976). 1982; 7:374. [PubMed: 7135070]

132. Quinnell RC, Stockdale HR. Flexion and extension radiography of the lumbar spine: a comparison with lumbar discography. Clin Radiol. 1983; 34:405. [PubMed: 6872445]

133. Torgerson WR, Dotter WE. Comparative roentgenographic study of the asymptomatic and symptomatic lumbar spine. J Bone Joint Surg Am. 1976; 58:850. [PubMed: 134040]

134. Panjabi M, Chang D, Dvorak J. An analysis of errors in kinematic parameters associated with in vivo functional radiographs. Spine (Phila Pa 1976). 1992; 17:200. [PubMed: 1553591] 
135. Shaffer WO, Spratt KF, Weinstein J, et al. 1990 Volvo Award in clinical sciences. The consistency and accuracy of roentgenograms for measuring sagittal translation in the lumbar vertebral motion segment. An experimental model. Spine (Phila Pa 1976). 1990; 15:741. [PubMed: 2237624]

136. Saraste H, Brostrom LA, Aparisi T, et al. Radiographic measurement of the lumbar spine. A clinical and experimental study in man. Spine (Phila Pa 1976). 1985; 10:236. [PubMed: 3992342]

137. Danielson B, Frennered K, Irstam L. Roentgenologic assessment of spondylolisthesis. I. A study of measurement variations. Acta Radiol. 1988; 29:345. [PubMed: 2968107]

138. Kalebo P, Kadziolka R, Sward L. Compression-traction radiography of lumbar segmental instability. Spine (Phila Pa 1976). 1990; 15:351. [PubMed: 2363064]

139. Wall MS, Oppenheim WL. Measurement error of spondylolisthesis as a function of radiographic beam angle. J Pediatr Orthop. 1995; 15:193. [PubMed: 7745092]

140. Bey MJ, Kline SK, Tashman S, et al. Accuracy of biplane x-ray imaging combined with modelbased tracking for measuring in-vivo patellofemoral joint motion. J Orthop Surg Res. 2008; 3:38. [PubMed: 18771582]

141. Brown RH, Burstein AH, Nash CL, et al. Spinal analysis using a three-dimensional radiographic technique. J Biomech. 1976; 9:355. [PubMed: 932049]

142. Li G, Wuerz TH, DeFrate LE. Feasibility of using orthogonal fluoroscopic images to measure in vivo joint kinematics. J Biomech Eng. 2004; 126:314. [PubMed: 15179865]

143. Stokes IA, Wilder DG, Frymoyer JW, et al. 1980 Volvo award in clinical sciences. Assessment of patients with low-back pain by biplanar radiographic measurement of intervertebral motion. Spine (Phila Pa 1976). 1981; 6:233. [PubMed: 6455745]

144. Suh CH. The fundamentals of computer aided X-ray analysis of the spine. J Biomech. 1974; 7:161. [PubMed: 4600718]

145. Wilder DG, Seligson D, Frymoyer JW, et al. Objective measurement of L4-5 instability. A case report. Spine (Phila Pa 1976). 1980; 5:56. [PubMed: 6444764]

146. Wachowski MM, Mansour M, Lee C, et al. How do spinal segments move? J Biomech. 2009; 42:2286. [PubMed: 19682692]

147. Nagerl H, Hawellek T, Lehmann A, et al. Non-linearity of flexion-extension characteristics in spinal segments. Acta Bioeng Biomech. 2009; 11:3. [PubMed: 20405809]

148. Rousseau MA, Bradford DS, Hadi TM, et al. The instant axis of rotation influences facet forces at L5/S1 during flexion/extension and lateral bending. Eur Spine J. 2006; 15:299. [PubMed: 16175392]

149. Huang RC, Girardi FP, Cammisa FP Jr, et al. The implications of constraint in lumbar total disc replacement. J Spinal Disord Tech. 2003; 16:412. [PubMed: 12902958]

150. Resnick DK, Weller SJ, Benzel EC. Biomechanics of the thoracolumbar spine. Neurosurg Clin N Am. 1997; 8:455. [PubMed: 9314515]

151. Bogduk N, Amevo B, Pearcy M. A biological basis for instantaneous centres of rotation of the vertebral column. Proc Inst Mech Eng H. 1995; 209:177. [PubMed: 8519407]

152. Haher TR, O'Brien M, Felmly WT, et al. Instantaneous axis of rotation as a function of the three columns of the spine. Spine (Phila Pa 1976). 1992; 17:S149. [PubMed: 1631714]

153. Mimura M. Rotational instability of the lumbar spine--a three-dimensional motion study using biplane X-ray analysis system. Nippon Seikeigeka Gakkai Zasshi. 1990; 64:546. [PubMed: 2230419]

154. Pearcy MJ, Bogduk N. Instantaneous axes of rotation of the lumbar intervertebral joints. Spine (Phila Pa 1976). 1988; 13:1033. [PubMed: 3206297]

155. Gertzbein SD, Seligman J, Holtby R, et al. Centrode characteristics of the lumbar spine as a function of segmental instability. Clin Orthop Relat Res. 1986; 48

156. Ogston NG, King GJ, Gertzbein SD, et al. Centrode patterns in the lumbar spine. Baseline studies in normal subjects. Spine (Phila Pa 1976). 1986; 11:591. [PubMed: 3787325]

157. Friberg O. Lumbar instability: a dynamic approach by traction-compression radiography. Spine (Phila Pa 1976). 1987; 12:119. [PubMed: 2954216] 
158. Panjabi MM, Andersson GB, Jorneus L, et al. In vivo measurements of spinal column vibrations. J Bone Joint Surg Am. 1986; 68:695. [PubMed: 3722226]

159. Pope MH, Wilder DG, Jorneus L, et al. The response of the seated human to sinusoidal vibration and impact. J Biomech Eng. 1987; 109:279. [PubMed: 2961931]

160. Selvik G. Roentgen stereophotogrammetry. A method for the study of the kinematics of the skeletal system. Acta Orthop Scand Suppl. 1989; 232:1. [PubMed: 2686344]

161. Haughton VM, Rogers B, Meyerand ME, et al. Measuring the axial rotation of lumbar vertebrae in vivo with MR imaging. AJNR Am J Neuroradiol. 2002; 23:1110. [PubMed: 12169466]

162. Rogers BP, Haughton VM, Arfanakis K, et al. Application of image registration to measurement of intervertebral rotation in the lumbar spine. Magn Reson Med. 2002; 48:1072. [PubMed: 12465120]

163. Dickey JP, Pierrynowski MR, Bednar DA, et al. Relationship between pain and vertebral motion in chronic low-back pain subjects. Clin Biomech (Bristol, Avon). 2002; 17:345.

164. Anderst, W.; Donaldson, W.; Lee, J., et al. Fused and Adjacent Segment Motion in the Cervical Spine 6 Months after Anterior Cervical Discectomy and Fusion. 56th Annual Meeting of the Orthopaedic Research Society; New Orleans, LA. p. 146

165. Li G, Wang S, Passias P, et al. Segmental in vivo vertebral motion during functional human lumbar spine activities. Eur Spine J. 2009; 18:1013. [PubMed: 19301040]

166. Pearcy M, Portek I, Shepherd J. Three-dimensional x-ray analysis of normal movement in the lumbar spine. Spine (Phila Pa 1976). 1984; 9:294. [PubMed: 6374922]

167. Pearcy MJ. Stereo radiography of lumbar spine motion. Acta Orthop Scand Suppl. 1985; 212:1. [PubMed: 3859987]

168. Lim TH, Eck JC, An HS, et al. A noninvasive, three-dimensional spinal motion analysis method. Spine (Phila Pa 1976). 1997; 22:1996. [PubMed: 9306529]

169. Ochia RS, Inoue N, Renner SM, et al. Three-dimensional in vivo measurement of lumbar spine segmental motion. Spine (Phila Pa 1976). 2006; 31:2073. [PubMed: 16915091]

170. Ochia RS, Inoue N, Takatori R, et al. In vivo measurements of lumbar segmental motion during axial rotation in asymptomatic and chronic low back pain male subjects. Spine (Phila Pa 1976). 2007; 32:1394. [PubMed: 17545906]

171. Takeuchi, T.; Shea, M.; White, AA. Correlation of magnetic resonance relaxation times with degeneration and biomechanical properties in human lumbar intervertebral disks. 38th Annual Meeting of the Orthopaedic Research Society; Washington, DC. p. 191

172. Toyone T, Takahashi K, Kitahara H, et al. Vertebral bone-marrow changes in degenerative lumbar disc disease. An MRI study of 74 patients with low back pain. J Bone Joint Surg Br. 1994; 76:757. [PubMed: 8083266]

173. Barbir A, Godburn KE, Michalek AJ, et al. Effects of Torsion on Intervertebral Disc Gene Expression and Biomechanics, Using a Rat Tail Model. Spine (Phila Pa 1976). 2010 In Press.

174. Espinoza Orias AA, Malhotra NR, Elliott DM. Rat disc torsional mechanics: effect of lumbar and caudal levels and axial compression load. Spine J. 2009; 9:204. [PubMed: 18495544]

175. Veres SP, Robertson PA, Broom ND. The influence of torsion on disc herniation when combined with flexion. Eur Spine J. 1468; 19

176. Yang, KH.; An, HS.; Ochia, RS., et al. In vivo measurement changes in lumbar facet joint width during torsion. 51st Annual Meeting of the Orthopaedic Research Society; Washington, DC. p. 690

177. Adams MA, Hutton WC. The relevance of torsion to the mechanical derangement of the lumbar spine. Spine (Phila Pa 1976). 1981; 6:241. [PubMed: 7268544]

178. Farfan HF, Cossette JW, Robertson GH, et al. The effects of torsion on the lumbar intervertebral joints: the role of torsion in the production of disc degeneration. J Bone Joint Surg Am. 1970; 52:468. [PubMed: 5425641] 


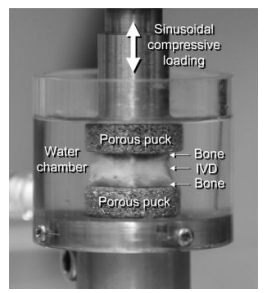

Figure 1.

Experimental test chamber for an unconfined dynamic compression experiment to record viscoelastic properties of a rabbit disc. The bone-disc-bone complex was secured between two porous pucks that prevented friction of the endplates with respect to these structures. Discs can be altered chemically to promote and recover from degeneration. Their dynamic viscoelastic properties can be assessed in this way. 


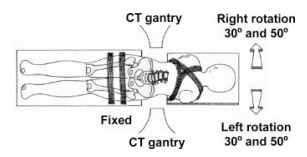

Figure 2.

Schematic of a subject's positioning inside a CT gantry to study torso rotation. Straps hold subject onto a torso rotation apparatus and CT records evidence of coupled motion during torsion. Segmental movements are level dependent and a pattern of the segmental movement is different between healthy subjects and subjec ts with low back pain. 


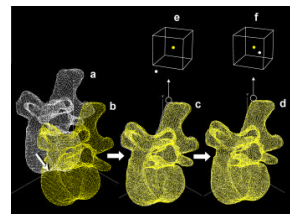

Figure 3.

Description of the Volume Merge method for analysis of segmental movement. A vertebral body in the neutral position (a) was virtually rotated and translated toward the rotated position (b). The position was refined with $0.05^{\circ}$ and $0.05 \mathrm{~mm}$ increments, respectively, until the maximized volume merging was determined (d). A voxel with a dimension of $1.0 \times 1.0 \times 1.0 \mathrm{~mm}$ was created for each point of the stationary target. The number of points of the moving vertebra (white dots) that fell within the voxel of the stationary target (yellow dots) was determined and the percentage of volume merge was defined: e) no volume merge, f) volume merge achieved within the voxel region of interest. 